\title{
Nano-realgar Inhibits the Proliferation of Bladder Cancer Cell and Induces the Expression of Apoptosis-related Proteins
}

\author{
Kewen Zheng \\ Department of Urology, The First Affiliated Hospital of Wenzhou Medical University, The First Clinical College of Wenzhou Medical \\ University, Wenzhou City, R. P. China \\ Email address: \\ zkw2121@163.com

\section{To cite this article:} \\ Kewen Zheng. Nano-realgar Inhibits the Proliferation of Bladder Cancer Cell and Induces the Expression of Apoptosis-related Proteins. \\ International Journal of Clinical Urology. Vol. 3, No. 2, 2019, pp. 46-49. doi: 10.11648/j.ijcu.20190302.14
}

Received: October 15, 2019; Accepted: November 1, 2019; Published: November 12, 2019

\begin{abstract}
Background The main component of realgar is arsenic disulfide (As2S2). Modern medical research shows that realgar can inhibit tumorigenesis and development of tumor by regulating cell proliferation and apoptosis. However, the lack of the traditional realgar preparations present with lower bioavailability, which further affects the therapeutic effect. With the improvement of new drug preparation processes, nano-androgen is increasingly used for anti-tumor drugs. Objective In order to investigate the effect of nano-realgar on proliferation of bladder cancer cell line RT4, we performed the research. Methods Nano-realgar was prepared by mechanical milling method. RT4 cell was used as target cell. MTT assay was used to detect the proliferation of RT4 cell treated with nano-realgar. And western blot was used to detect the expression of apoptosis-related proteins (Bax, Caspase-3) in the RT4 cell treated with nano-realgar. Results Nano-realgar could significantly inhibit the proliferation of RT4 cell. After treated with 10 $\mathrm{ug} / \mathrm{ml}, 20 \mathrm{ug} / \mathrm{ml}$ and $40 \mathrm{ug} / \mathrm{ml}$ nano-realgar for $24 \mathrm{~h}$ and $48 \mathrm{~h}$, the proliferation inhibition rate of RT4 cell increased significantly compared with the negative control group $(\mathrm{P}<0.05)$, and the expression of apoptosis-related proteins, Bad and Caspase-3, increased significantly after treated with $20 \mathrm{ug} / \mathrm{ml}$ and $40 \mathrm{ug} / \mathrm{ml}$ nano-realgar for $48 \mathrm{~h}(\mathrm{P}<0.05)$. Conclusion Nano-realgar can inhibit the proliferation of RT4 cell, and induces the expression of Bax and Caspase-3.
\end{abstract}

Keywords: Proliferation, Nano-realgar, Bax, Caspase-3, Bladder Cancer Cell

\section{Introduction}

Bladder cancer is one of the most common malignant tumors in the urinary system, which seriously threatens human life and health [1]. According to statistics, the number of new bladder cancer patients worldwide is more than 300,000 every year [1]. Bladder cancer is divided into nonmuscular invasive bladder cancer (NMIBC) and muscular invasive bladder cancer (MIBC). The main treatment of NMIBC is mainly transurethral resection of bladder tumors (TURBT) combined with postoperative intravesical chemotherapy [2]. Studies have shown that the recurrence rate of tumors after TURBT is as high as $60 \%-70 \%$ in 5 years, and about $25 \%$ of patients will progress to muscular invasive bladder cancer [3, 4]. In view of the instability efficacy of intravesical chemotherapy for bladder cancer, it is necessary to develop more effective drug with less impact on life quality of patients after operation.

The main component of realgar is arsenic disulfide (As2S2) [5]. With the increase of clinical researches in recent years, realgar has been accepted and recognized as a safe and effective oral anti-hematological malignancy drug [7-9]. It has been used as second-line chemotherapeutic drugs in the treatment of hematological malignancies such as chronic myeloid leukemia (CML), acute promyelocytic leukemia (APL) and polycythemia vera (PV) in China [7-9]. In recent years, more and more scholars have tried to use realgar in the treatment of solid tumors, and achieved gratifying results [10-12]. Nano-realgar improve the solubility and bioavailability of realgar, and show stronger and broader anti-tumor effect [13]. However, the research on effect of realgar on bladder cancer cell is not so systematic and deepgoing. Studies have shown that Bax and Caspase-3 play an important role in the proliferation and apoptosis of cells [14, 
15]. In order to explore the effect of nano-realgar on the proliferation of bladder cancer cell we observed the growth of RT4 cell treated with different concentration of nanorealgar at different time points, and the changes of Bax and Caspase-3 expression levels was observed as well.

\section{Methods and Material}

\subsection{Preparation of Nano-realgar}

The experiment was completed in supercritical $\mathrm{CO}_{2}$ booster tank contained with high energy ball milling module. $1-2 \mathrm{~g}$ realgar powder (Alfa Aesar Company) was added to the ball mill. The agate ball mill with the ball material ratio of 4:1-16:1 $(\mathrm{w} / \mathrm{w})$ was put into the ball mill. The speed of the ball mill was set at 20-40 Hz. $\mathrm{CO}_{2}$ was added after sealing the booster tank. The temperature in the tank was controlled to $40^{\circ} \mathrm{C}$, and the pressure was kept at $100 \mathrm{~B}$. After milling for 1-12 h, the nanorealgar powder was obtained by rapidly discharging the pressure in the tank. The average particle size of the polished realgar particles is less than or equal to $70 \mathrm{~nm}$ as a standard.

\subsection{Cell Culture and Grouping}

The T24 human BCC was purchased from Procell Co., Ltd. T24 cell was taken out from the refrigerator and melted in water bath at $37^{\circ} \mathrm{C}$ for less than 1 minute. T24 cells were cultured in RPMI-1640 medium containing $10 \%$ fetal bovine serum $(100 \mathrm{U} / \mathrm{ml}$ penicillin and $0.1 \mathrm{mg} / \mathrm{l}$ streptomycin) and grown at $37^{\circ} \mathrm{C}$ and $5 \% \mathrm{CO}_{2}$. The cells were subcultured when they reached $\sim 80 \%$ confluence.

The experiment was divided into negative control group and nano-realgar group. In the nano-realgar group, RT4 cells were cultured in $20 \mathrm{ug} / \mathrm{ml}$ and $40 \mathrm{ug} / \mathrm{ml}$ of nano-realgar with RPMI-1640 medium for $24 \mathrm{~h}$ and $48 \mathrm{~h}$.

\subsection{MTT Assay for Cell Proliferation Activity}

Cells in logarithmic growth phase were cultured overnight in an incubator at $5 \% \mathrm{CO}_{2}$ and $37^{\circ} \mathrm{C}$ for $4 \mathrm{~h}$ after adjusting the cell density to $5 \times 104$ cells $/ \mathrm{ml}$. The cells were seeded in a 96-well plate, in $100 \mu \mathrm{l}$ cell suspension, and then cultured in a constant temperature incubator at $5 \% \mathrm{CO}_{2}$ and $37^{\circ} \mathrm{C}$ for 4 h. After incubating at $37^{\circ} \mathrm{C}$ for $4 \mathrm{~h}, 150 \mu \mathrm{DMSO}$ was added and shaken for $10 \mathrm{~min}$. The absorbance value of the optical density (OD) of each well at a wavelength of $568 \mathrm{~nm}$ was measured with a microplate reader.

\subsection{Western Blot for Analysis of Bax and Caspase-3}

Western blot was used to detect the changes of apoptosisrelated proteins Bax and Caspase- 3 in cells treated with nano-realgar. First, SDS-PAGE electrophoresis was used to isolate the proteins in the lysate of RT4 cell treated with nano-realgar. After transmembrane, the blocking solution was blocked at $37^{\circ} \mathrm{C}$ for $1 \mathrm{~h}$, then the second antibody was added and incubated overnight at $4^{\circ} \mathrm{C}$. TBST was washed three times for 10 minutes each time. The expression level was detected by ECL chemiluminescence detection kit.

\subsection{Statistical Analysis}

Statistical analysis was performed using SPSS 22.0 statistical software (SPSS, Inc.). Data were expressed as the mean \pm standard deviation, and an ANOVA and a post hoc test for multiple comparisons was used for comparisons between groups. $\mathrm{P}<0.05$ was considered to indicate a statistically significant difference.

\section{Results}

\subsection{MTT Assay to Detect the Inhibitory Effect of Different Concentrations of Nano-realgar on the Proliferation of RT4 Cell}

MTT result showed that the proliferation inhibition rate of nano-realgar group $(10 \mathrm{ug} / \mathrm{ml}, 20 \mathrm{ug} / \mathrm{ml}$ and $40 \mathrm{ug} / \mathrm{ml})$ were significantly higher than that of control group at $24 \mathrm{~h}$ and $48 \mathrm{~h}$ respectively $(\mathrm{P}<0.05)$, and with the increase of concentration, the cell proliferation inhibition rate increased $(\mathrm{P}<0.05)$. There was no significant difference of cell proliferation inhibition rate between nano-realgar group at $48 \mathrm{~h}$ and $24 \mathrm{~h}$ with the concentration of $10 \mathrm{ug} / \mathrm{ml}$. The cell proliferation inhibition rate of nano-realgar group at $48 \mathrm{~h}$ were significantly higher than that of at $24 \mathrm{~h}$ with the concentration of $20 \mathrm{ug} / \mathrm{ml}$ and $40 \mathrm{ug} / \mathrm{ml}(\mathrm{P}<$ 0.05 ) as shown in Table 1.

Table 1. Proliferation inhibition rate of different concentrations of nanorealgar on $R T 4$ cell (\%).

\begin{tabular}{lllll}
\hline time & control & $\mathbf{1 0 u g} / \mathbf{m l}$ & $\mathbf{2 0 u g} / \mathbf{m l}$ & $\mathbf{4 0 u g} / \mathbf{m l}$ \\
\hline $24 \mathrm{~h}$ & $1.21 \pm 0.11$ & $10.51 \pm 2.64$ & $15.32 \pm 3.57$ & $37.53 \pm 4.46$ \\
$48 \mathrm{~h}$ & $2.57 \pm 0.34$ & $12.31 \pm 2.31$ & $25.87 \pm 3.46$ & $53.43 \pm 4.98$ \\
\hline
\end{tabular}

\subsection{Western Blot of Bax and Caspase-3 in Bladder Cancer RT4 Cell Treated with Nano-realgar}

Western blot results indicated that the expression of Bax and Caspase- 3 protein of RT4 cells increased significantly $48 \mathrm{~h}$ after the treatment with $20 \mathrm{ug} / \mathrm{ml}$ and $40 \mathrm{ug} / \mathrm{m}$ of nano-reaglar compared with negative control group ( $\mathrm{P}<0.05)$. And the expression levels of Bax and Caspase-3 protein of RT4 cell treated with $40 \mathrm{ug} / \mathrm{m}$ of nano-reaglar were higher than that treated with $20 \mathrm{ug} / \mathrm{m}$ of nanoreaglar $(\mathrm{P}<0.05)$, as shown in Figure 1 .

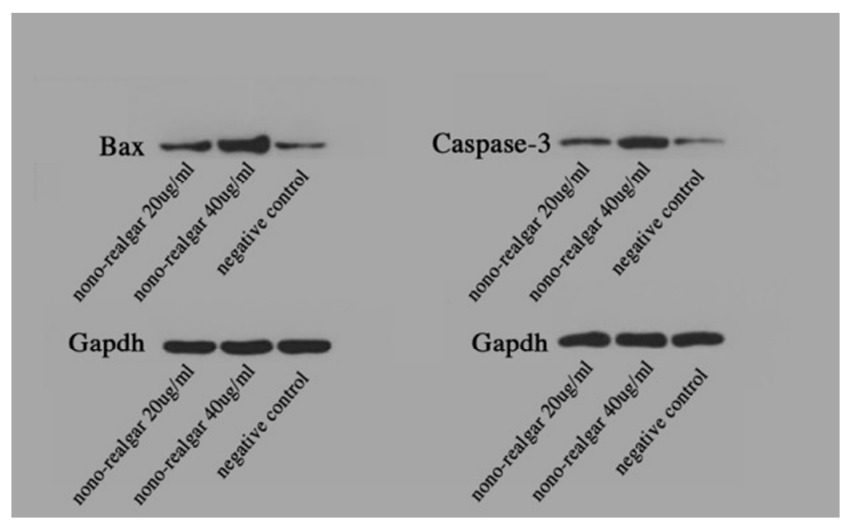

Figure 1. Effect of nano-realgar on the expression of Bax and Caspase-3 in bladder cancer RT4 cell. 


\section{Discussion}

Bladder cancer is a malignant tumor that seriously threatens the safety of human life. Bladder cancer is divided into NMIBC and MIBC. The main therapies for NMIBC are radical cystectomy, systemic chemotherapy and radiotherapy, while TURBT combined with postoperative intravesical chemotherapy is the main treatment for NMIBC $[1,2]$. 75$85 \%$ of the patients are NMIBC at the first diagnosis, and the recurrence rate of tumor in 5 years after TUR-Bt is as high as $60 \%-70 \%[3,4]$. Due to the high incidence of NMIBC and high recurrence rate after operation, it is necessary to develop more effective drug for the treatment of bladder cancer.

Realgar is one of the most important drugs in traditional Chinese medicine [8,9]. It has been wildly used to treat carbuncle, furuncle, snake bite, wormy abdominal pain, epilepsy, malaria and so on in China [8, 9]. Modern medical research shows that nano-realgar can play a biological role in inhibiting malignant tumors such as cervical cancer, gastric cancer, liver cancer, breast cancer, osteosarcoma, glioma and [10-12, 16-18]. Nano-realgar can inhibit cell DNA synthesis, inhibit proliferation of cancer cells, enhance cellular immunity and other biological [19]. In our research, the result indicated that nano-realgar tended to be inhibitory effective on the growth of bladder cancer cell, and the inhibitory effect of nano-realgar on the growth of bladder cancer cell tended to be concentration related. And the inhibitory effect of nano-realgar tended to be time related as well for cell proliferation inhibition rate of nano-realgar group at $48 \mathrm{~h}$ were significantly higher than that of at $24 \mathrm{~h}$ with the concentration of $20 \mathrm{ug} / \mathrm{ml}$ and $40 \mathrm{ug} / \mathrm{ml}$.

And the expression of apoptosis related proteins increased after treated with nano-realgar in RT4 cell. Bax is one of the most important apoptotic gene in human. Bax belongs to the Bcl-2 gene family [14]. The encoded Bax protein can form heteromeric dipolymer with $\mathrm{Bcl}-2$ and inhibit the production of Bcl-2. The over expression of Bax can antagonize the protective effect of Bcl-2 and induces the apoptosis [14]. It is generally believed that Caspase- 3 is the most important endshearing enzyme in the process of apoptosis, and also an important component of cytotoxic $\mathrm{T}$ lymphocyte killing mechanism [15]. Caspase-3 plays an irreplaceable role in apoptosis [15]. In our research, western blot showed that the protein expression of Caspase-3 and Bax increased significantly after treatment of nano-realgar compared with negative control group, and the expression levels of Bax and Caspase- 3 protein of RT 4 cell treated with $40 \mathrm{ug} / \mathrm{m}$ of nanoreaglar were higher than that treated with $20 \mathrm{ug} / \mathrm{m}$ of nanoreaglar.

\section{Conclusion}

In conclusion, this study shows that nano-realgar can induce the expression of Bax and Caspase- 3 and inhibit the proliferation of bladder cancer cell, which indicate nanorealgar has potential therapeutic value for bladder cancer. However, more However, more further studies on mechanisms and animal experiments are still needed.

\section{Acknowledgements}

The present study was supported by research fund NO. LQ17H050002 and Y20160336.

\section{References}

[1] Antoni, S., Ferlay, J., Soerjomataram, I., Znaor, A., Jemal, A., and Bray, F., "Bladder Cancer Incidence and Mortality: A Global Overview and Recent Trends", Eur Urol, 71 (1). 96108. Jan. 2016.

[2] Babjuk, M., Böhle, A., Burger, M., et al., "EAU Guidelines on Non-Muscle-invasive Urothelial Carcinoma of the Bladder: Update 2016", Eur urol, 71 (3). 447-461. Mar. 2017.

[3] Adam, K., Peter, D., and Howard, E., "Recurrence and upstaging rates of T1 high-grade urothelial carcinoma of the bladder on repeat resection in a Canadian, resource-limited, healthcare system", Can Urol Assoc J, 12 (8). 267-269. Aug. 2018.

[4] Gordon, PC., Thomas, F., Noon, AP., Rosario, DJ., and Catto, JWF., "Long-term Outcomes from Re-resection for High-risk Non-muscle-invasive Bladder Cancer: A Potential to Rationalize Use", Eur Urol Focus. 5 (4). 650-657. July. 2017.

[5] Wu, J., Shao, Y., Liu, J., Chen, G. and Ho, PC., "The medicinal use of realgar (As4S4) and its recent development as an anticancer agent", Journal of Ethnopharmacology, 135 (3). 595-602. Jun. 2011.

[6] Ding, W., Zhang, L., Kim, S., et al, "Arsenic sulfide as a potential anti-cancer drug", Mol Med Rep, 11 (2). 968-74. Feb. 2015.

[7] Zhu, HH., Hu, J., Lo-Coco, F., and Jin, J., "The Simpler the Better: Oral Arsenic for Acute Promyelocytic Leukemia", Blood, 134 (7). 597-605. Aug. 2019.

[8] Liu, J., Wei, LX., Wang, Q., et al, "A review of cinnabar and/or realgar-containing traditional medicines", Journal of Ethnopharmacology,, 10 (210). 340-350. Jan. 2018.

[9] Li, Y., Wang, D., Xu, Y., et al, "Use status and metabolism of realgar in Chinese patent medicine", Journal of ethnopharmacology, pii: S0378-8741 (15) 00236-6. Apr. 2015.

[10] Lijie, LI., Luying, W., Songshu, X., Li, Y., Cheng, C., and Xue, M., "Effect of nano-realgar on proliferation and apoptosis of human cervical carcinoma cells", Journal of Central South University (Medical Science), 40 (10). 1068-75. Oct. 2015.

[11] Siyu, C., Lian, Z., Sungkyoung, K., et al, "Arsenic sulfide inhibits cell migration and invasion of gastric cancer in vitro and in vivo" Drug Design, Development and Therapy, 9 (9). 5579-90. Oct. 2015.

[12] Qin, Y., Wang, H., Liu, Z., Liu, J., Wu, JZ., "Realgar quantum dots induce apoptosis and necrosis in HepG2 cells through endoplasmic reticulum stress", Biomedical Reports, 3 (5). 657-662. Sep. 2015. 
[13] Baláž, P., and Sedlák, J., "Arsenic in Cancer Treatment: Challenges for Application of Realgar Nanoparticles (A Minireview) ", Toxins, 2 (6). 1568-1581. Sep. 2010.

[14] Renault, TT., Dejean, LM., and Manon, S., "A brewing understanding of the regulation of Bax function by Bcl-xL and Bcl-2", Mechanisms of ageing and development, 161 (Pt B). 201-210. Jan. 2016.

[15] Balal, K., Nasrin, S., Saydan, KG., et al, "Advances in nanomaterial based optical biosensing and bioimaging of apoptosis via caspase-3 activity: a review", Microchimica Acta, 185 (9). 434. Aug. 2018.

[16] Zhao, Y., Yuan, B., Onda, K., "Anticancer efficacies of arsenic disulfide through apoptosis induction, cell cycle arrest, and pro-survival signal inhibition in human breast cancer cells", Am J Cancer Res, 8 (3). 366-386. Mar. 2018.
[17] Wang, G., Zhang, T., Sun, W., et al, "Arsenic sulfide induces apoptosis and autophagy through the activation of ROS/JNK and suppression of Akt/mTOR signaling pathways in osteosarcoma", Free Radical Biology and Medicine, 106.2437. May. 2017.

[18] An, YL., Nie, F., Wang, ZY., Zhang, DS., "Preparation and characterization of realgar nanoparticles and their inhibitory effect on rat glioma cells", International Journal of Nanomedicine, 6 (1). 3187-94. Dec. 2011.

[19] Xiaobo, W., Ye, T., Ronggang, X., et al, "Enhanced antitumor activity of realgar mediated by milling it to nanosize", International Journal of Nanomedicine, 9: 745-57. Jan. 2014. 